\title{
Tics as an initial manifestation of juvenile Huntington's disease: case report and literature review
}

\author{
Shi-Shuang Cui ${ }^{\dagger}$, Ru-Jing Ren ${ }^{\dagger}$, Ying Wang ${ }^{*}$, Gang Wang ${ }^{*}$ (D) and Sheng-Di Chen
}

\begin{abstract}
Background: Huntington's disease (HD) is an autosomal dominant disorder, typically characterized by chorea due to a trinucleotide repeat expansion in the HTT gene, although the clinical manifestations of patients with juvenile HD (JHD) are atypical.

Case presentation: A 17-year-old boy with initial presentation of tics attended our clinic and his DNA analysis demonstrated mutation in the HTT gene (49 CAG repeats). After treatment, his symptoms improved. Furthermore, we performed literature review through searching the databases and summarized clinical features in $33 \mathrm{JHD}$ patients.

Conclusion: The most prevalent symptoms are ataxia, and two cases reported that tics as initial and prominent manifestation in JHD. Among them, 88\% patients carried CAG repeats beyond 60 and most of them have family history. This case here illustrates the variable range of clinical symptoms of JHD and the necessity of testing for the HD mutation in young patients with tics with symptoms unable to be explained by Tourette's syndrome (TS).
\end{abstract}

Keywords: Juvenile Huntington's disease, Tics, Case report, Literature review

\section{Background}

Huntington's disease (HD) is an autosomal dominant movement disorder, typically characterized by chorea, cognitive decline, and behavioral changes, due to a trinucleotide (CAG) repeat expansion in the HTT gene. Healthy individuals typically have fewer than 35 CAG repeats, and repeats of 40 or above cause HD with complete penetrance [1]. Except for Chorea, other symptoms include eye-movement abnormalities, parkinsonism, dystonia, myoclonus, tics, ataxia, dysarthria and dysphagia, and spasticity with hyperreflexia [1]. Its age at onset (AAO) ranges from 1.5 to 85 years [2]. Here we report a boy whose prominent symptoms were those typically associated with Tourette's syndrome (TS) initiated at age of 9, confirmed HD with the presence of expanded CAG repeats.

\footnotetext{
* Correspondence: wang-ying@medmail.com.cn; wgneuron@hotmail.com ${ }^{\dagger}$ Equal contributors

Department of Neurology \& Neuroscience Institute, Ruijin Hospital affiliated to Shanghai Jiao Tong University School of Medicine, Shanghai 200025, China
}

(c) The Author(s). 2017 Open Access This article is distributed under the terms of the Creative Commons Attribution 4.0 International License (http://creativecommons.org/licenses/by/4.0/), which permits unrestricted use, distribution, and reproduction in any medium, provided you give appropriate credit to the original author(s) and the source, provide a link to the Creative Commons license, and indicate if changes were made. The Creative Commons Public Domain Dedication waiver (http://creativecommons.org/publicdomain/zero/1.0/) applies to the data made available in this article, unless otherwise stated.
A 17-year-old boy first noted the gradual onset of prompt, repeated irregular tics of his head with uncontrolled eye blinking, frowning, and sometimes throat clearing 8 years ago. These involuntary movements had gradually involved in his shoulders, right upper limb and both lower limbs, and torticollis developed since 5 years earlier, exacerbated by anxiety and disappearing during sleep. The tics of right upper limb were worse with a heavy load and suppressed by himself occasionally. $\mathrm{He}$ complained about both inattention and hyperactivities in class when studying in school. He had been inclined to obsessive hand washing in the last 5 years, and had night terrors occasionally which could not be recalled anything after sleeping. He denied the presence of choreic movement, loss of consciousness, urinary or fecal incontinence and obvious cognitive decline. He had been to several hospitals without confirmed diagnosis and taken Chinese traditional medicine irregularly.

The patient was full-term. His birth and developmental milestones were normal and he denied any disease including diabetes mellitus and carpal tunnel syndrome. 
$\mathrm{He}$ is in high school and of mid-ranking. His younger brother is healthy and he had no family history of neurologic disorders including tics, HD, obsessive-compulsive disorder (OCD), attention deficit hyperactivity disorder (ADHD). Past medical history reveals no history of head injury, surgery and streptococcus infection. His parents also deny any symptoms of tics, HD, OCD and ADHD.

The most prominent finding of neurologic examination was the presence of multifocal tics manifested chiefly by blinking, frowning, head jerking, shoulder shrugging. Physical examination showed a spasmodic torticollis and hypertrophic left sternocleidomastoideus muscle. Neuropsychiatric assessment revealed the evidence of mild depression with Self-Rating Depression Scale score of 54 (of 80), mild anxiety with Self-Rating Anxiety Scale score of 56 (of 80). The Mini-Mental State score was 29/30 and Montreal Cognitive Assessment score was 30/30, suggested that no evidence of cognitive impairment. Both Kayser-fleischer ring and choreic movement were absent. Deep reflexes were brisk and Babinski's sign was absent. Speech and muscle tone was normal.

Blood routine and smear, liver function, iron and copper metabolism were of normal range. Cranial Magnetic resonance imaging (MRI) including susceptibility weighted imaging (SWI) and diffusion weighted imaging (DWI) was unremarkable. Ambulatory electroencephalography (AEEG) implied paroxysmal epileptic discharges during sleep. Electromyography implied spontaneous activities of sternocleidomastoideus muscle and orbicularis oculi muscle, and cramp potential of sternocleidomastoideus muscle. DNA analysis confirmed HD mutation containing 49 CAG repeats. Genetic testing of his parents were both in normal range (his mother carried 18 /19 repeats and his father carried 16/19 repeats).

He was treated with valproic acid ( $25 \mathrm{mg}$ bid), tiapride hydrochloride (150 mg tid), and artane (2 mg tid) during hospitalization and after discharge. The amplitude and frequency of tics reduced obviously and the tics in his hand diminished without obvious adverse effects. We follow up him regularly so far.

\section{Discussion and conclusion}

Here we described a rare and interesting case of juvenile Huntington's disease (JHD), a significant minority of HD commence before the age of 20 years, which presented tics as initial and prominent symptom. A review of the literature yielded initial symptoms and DNA analysis in 33 JHD patients when we used "juvenile Huntington's disease”, “juvenile Huntington's chorea”,"Huntington's disease ",Huntington's chorea" and "case report", "clinical Study" for searching in PubMed, Embase, Cochrane Library, Web of Knowledge, CINAHL and ProQuest databases (Table 1). According to the results, unlike typically choreiform movement in adult-onset HD, the clinical manifestations of patients with JHD are atypical. The most prevalent symptoms are ataxia, followed by psychiatric manifestations, seizure, parkinsonism, dementia, dysphagia, dysarthria, and dystonia according to the previous reports (Table 1). Among them, two cases reported tics as initial and prominent manifestation in JHD, and only one with family history $[3,4]$. Here we first reported a case mimic tics with low-range abnormal expansion of CAG without family history.

Tics are classified as idiopathic, namely TS, and secondary. The patient in this case had child-onset symptoms of tics, OCD, and ADHD, a typical presentation of TS [5]. However, both symptom of cervical dystonia and the abnormal EEG are rarely mentioned in TS. Thus, we screened for tics due to other disorders, such as head trauma, stroke, certain drugs, toxins, post-infection, neuroacanthocytosis, iron deposition, Wilson disease (WD), and HD. WD, iron deposition could be excluded by the absence of KF ring, normal iron and copper metabolism, normal structural MRI imaging. Head trauma, post infection and toxins were also excluded since the patient denied histories of streptococcus infection, trauma, and drug abuse. Normal structural MRI excluded stroke. Neuroacanthocytosis was excluded due to absence of hemolysis and normal blood smear. HD could not be excluded and it may be presented as tics, dystonia, seizure, behavior disorder similar in this patients. Mejia NI and colleagues have analyzed data on 155 patients with tics who did not fulfill the diagnostic criteria for TS, and found one patient diagnosed as HD by DNA analysis [6]. Several cases have report tics in HD, presented as blinking, face contraction, sniffing, jerk and multiple tics [3, 7-9]. Considering HD has various atypical symptoms including tics, especially for JHD, we made a DNA analysis of this boy and found abnormal CAG repeats. In contrast to most tics in HD patients, which had adult-onset [7-10], the initiated onset age in the present case was 9, a prevalent age at of onset for TS. Another possibility is the coexistence of both TS and $\mathrm{HD}$ in this patient. However, the typical progressive wax and wane disease course of TS was absent in this case, which gives less priority to the comorbidity [10]. In addition, genetic causes for TS are unknown, which makes it impossible to testify the hypothesis from genetic perspective. Both HD and tics are somewhat associated to a dopaminergic system dysfunction, but the molecular mechanism for the relationship between HD and TS need further investigated in future $[11,12]$.

We noticed that most JHD patients occur in families in which HD was already present, and paternal inheritance is more common, compared with maternal pattern from the literature review. However, the patient in the present case had negative family history, included by the negative finding in DNA analysis of the parents. A de novo occurrence of JHD in a family, reported by Post B, 
Table 1 clinical manifestation of JHD with DNA analysis and family history

\begin{tabular}{|c|c|c|c|c|}
\hline patients & age at onset(year) & initial symptoms & Number of CAG repeats & Inheritance \\
\hline this case & 9 & tics & $47 / 19$ & no family history \\
\hline $1[21]$ & 6 & $\begin{array}{l}\text { character changes, anxiety, irritability, } \\
\text { distractibility }\end{array}$ & unknown & paternal \\
\hline 2 [13] & 2 & rigid & $250 / 19$ & maternal \\
\hline 3 [22] & 17 & balance and gait impairment & $62 / 22$ & paternal \\
\hline 4 [22] & 20 & balance and gait impairment & $61 / 22$ & paternal \\
\hline 5 [23] & 6 & seizure & 115 & paternal \\
\hline $6[24]$ & 2.5 & hypokinetic/rigid syndrome & 102 & unknown \\
\hline 7 [25] & 1 & dystonia, speech impairment & $256 / 14$ & paternal \\
\hline 8 [26] & 10 & depression & 71 & paternal \\
\hline 9 [27] & 3 & development delay, seizure & 214 & paternal \\
\hline $10[28]$ & 3.5 & cognitive decline & $84 / 15$ & maternal \\
\hline 11 [29] & 3.5 & speech impairment & 108 & maternal \\
\hline $12[30]$ & 3 & ataxia & $130-150 / 20$ & maternal \\
\hline $13[31]$ & 2 & dysarthria, ataxia & 53 & paternal \\
\hline $14[31]$ & 4 & dystonia & 69 & maternal \\
\hline 15 [31] & 8 & ataxia & 41 & paternal \\
\hline 16 [31] & 13 & visual hallucination & 66 & paternal \\
\hline 17 [32] & 16 & eating disorder & $55 / 17$ & unknown \\
\hline 18 [33] & 5 & lethargy, poor balance & greater than 64 & parental \\
\hline 19 [3] & 4 & excessive blinking & $108 / 47$ & parental \\
\hline 20 [34] & 5 & ADHD & 75 & no family history \\
\hline $21[35]$ & 2 & $\begin{array}{l}\text { oral motor dysfunction and gait } \\
\text { disturbance }\end{array}$ & $160 / 60$ & maternal \\
\hline $22[36]$ & 5 & behavioral disorders & $52 / 15$ & maternal \\
\hline $23[37]$ & 6 & seizure & $140 / 20$ & parental \\
\hline $24[38]$ & 1.5 & motor and speech delay & $210-250 / 35$ & parental \\
\hline 25 [39] & 3 & speech impairment & $95 / 17$ & no family history \\
\hline $26[40]$ & 20 & seizure & $60 / 21$ & parental \\
\hline 27 [41] & 15 & dystonia, parkinsonism & $67 / 30$ & $\begin{array}{l}\text { no family history, but father } \\
\text { carried a reduced penetrance } \\
\text { repeat }\end{array}$ \\
\hline 28 [42] & 6 & motor and speech regression & 72 & unknown \\
\hline $29[4]$ & 8 & seizure & $104 / 17$ & parental \\
\hline $30[4]$ & 10 & tics & $82 / 18$ & no family history \\
\hline $31[4]$ & 9 & cognitive decline & $76 / 17$ & parental \\
\hline $32[4]$ & 12 & ataxia & $74 / 17$ & parental \\
\hline 33 [43] & 8 & $\begin{array}{l}\text { falls, ataxic gait and bradykinesia, } \\
\text { seizure }\end{array}$ & 82 & no family history \\
\hline
\end{tabular}

$A D H D$ attention-deficit/hyperactivity disorder

was confirmed the presence of a reduced penetrance repeat in the paternal side and the CAG expansion between generations [13]. Unlike the case mentioned above, the DNA analysis of both parents in this case were negative, thus the repeat expansion in this sporadic HD is likely to be explained by the mutation of normal HD gene.
From literature review, a large expansion is seen in most JHD, of which 29(88\%) patients carried CAG repeats beyond 60, the largest reached 256. But CAG repeat of the present patient was below 60. Although longer CAG repeats predict earlier onset, CAG repeat length only accounts for about $60 \%$ of the variability 
[14]. The remaining are ascribed to additional genetic [15], environmental factors $[14,16]$ and other factors including somatic expansions in brain [17] or increasing in size [18].

The EEG in the patient in this case showed paroxysmal epileptic discharges during sleep without obvious seizure. Green JB and his colleagues have reported two JHD patients showing spikes in EEG without any type of seizure [19]. Positive spikes at $6-7$ and $14 \mathrm{~Hz}$ could be found in $20 \%$ of healthy controls [20]. The underlying mechanism remains unknown. Since the abnormal spikes appear during sleep, the symptoms may also appear during sleep undetectably. The local spontaneous activities might account for cervical dystonia and intensive excitement of muscle in shorten position might result in cramp potential.

In summary, this case underlines marked phenotypic variability of HD, especially in JHD. HD should be considered in patients with juvenile-onset tic, especially with symptoms can't be totally explained by TS, even in case of a negative family history although TS may be more prevalent. According to clinical phenomenology, we could not make the diagnosis of HD without genetic test. Therefore, molecular genetic test will became more helpful for the precision medicine of movement disorders in future. The further investigation should be focus on the relationship between TS and HD, especially at the level of pathophysiology and genetic etiology.

\begin{abstract}
Abbreviations
AAO: Age at onset; ADHD: Attention deficit hyperactivity disorder; AEEG: Ambulatory electroencephalography; DWI: Diffusion weighted imaging; HD: Huntington's disease; JHD: Juvenile Huntington's disease JHD; MRI: Magnetic resonance imaging; OCD: Obsessive-compulsive disorder; SWI: Susceptibility weighted imaging; TS: Tourette's syndrome
\end{abstract}

\section{Acknowledgments}

We are grateful to the patient who participated in this study. The authors thank Con. A/Prof. Yue Huang at University of New South Wales, Australia for critical reading of the manuscript.

\section{Funding}

None.

\section{Availability of data and materials}

All data generated or analyzed during this study are included in this published article.

\section{Authors' contributions}

SC drafted the manuscript and analyzed; RR acquired clinical information and managed patient; GW, YW and SC conceptualized and revised the manuscript; GW revised the final approval of the version to be published. All authors read and approved the contents of the case report.

\section{Ethics approval and consent to participate}

The study was approved by the medical ethics committee of Ruilin Hospital affiliated to Shanghai Jiao Tong University School of Medicine.

\section{Consent for publication}

Written informed consent was obtained from the patient's parent for publication of this case report.

\section{Competing interests}

The authors declare that they have no competing interests.

\section{Publisher's Note}

Springer Nature remains neutral with regard to jurisdictional claims in published maps and institutional affiliations.

Received: 16 December 2016 Accepted: 14 July 2017

Published online: 08 August 2017

\section{Reference}

1. Cardoso F, Seppi K, Mair KJ, Wenning GK, Poewe W. Seminar on choreas. Lancet Neurol. 2006 Jul:5(7):589-602.

2. Sun YM, Zhang YB, Wu ZY. Huntington's Disease: Relationship Between Phenotype and Genotype. Mol Neurobiol. 2017:54(1):342-8.

3. Xing SH, Chen L, Chen X, Pei Z, Zeng J, Li J. Excessive blinking as an initial manifestation of juvenile Huntington's disease. Neurol Sci. 2008:29:275-7.

4. Liu ZJ, Sun YM, Ni W, Dong Y, Shi SS, Wu ZY. Clinical features of Chinese patients with Huntington's disease carrying CAG repeats beyond 60 within HTT gene. Clin Genet. 2014 Feb;85(2):189-93.

5. Hirschtritt ME, Lee PC, Dion Y, Grados MA, Illmann C, King RA, Sandor P, McMahon WM, Lyon GJ, Cath DC, Kurlan R, Robertson MM, Osiecki L, Scharf JM, Mathews CA. Tourette Syndrome Association International Consortium for Genetics. Lifetime prevalence, age of risk, and genetic relationships of comorbid psychiatric disorders in Tourette syndrome. JAMA Psychiatry. 2015 Apr;72(4):325-33.

6. Mejia NI, Jankovic J. Secondary tics and tourettism. Rev Bras Psiquiatr. 2005 Mar;27(1):11-7.

7. Becker N, Munhoz RP, RaskinS WLC, Teive HA. Non-Choric Movement Disorders As Initial Manifestations of Huntington's Disease. ArqNeuropsiquiatr. 2007;65(2-B): 402-5.

8. Jankovic J, Ashizawa T. Tourettism associated with Huntington's disease. Mov Disord. 1995;10(1):103-5.

9. Colosimo C. A case of atypical adult-onset tic disorder. Neurologist. 2015 Apr:19(4):99-100.

10. Kerbeshian J, Burd L, Leech C, Rorabaugh A. Huntington's disease and childhood onset Tourette syndrome. Am J Med Genet. 1991;39(1):1-3.

11. Müller N. Tourette's syndrome: clinical features, pathophysiology, and therapeutic approaches. Dialogues Clin Neurosci. 2007:9(2):161-71.

12. Rikani AA, Choudhry Z, Choudhry AM, et al. The mechanism of degeneration of striatal neuronal subtypes in Huntington disease. Ann Neurosci. $2014 \mathrm{Jul}$; 21(3):112-4. doi:10.5214/ans.0972.7531.210308.

13. Nance MA, Mathias-Hagen V, Breningstal G, Wick MJ, McGlennen RC. Analysis of a very large trinucleotide repeat in a patient with juvenile Huntington's disease. Neurology. 1999 Jan;52:392-4.

14. Wexler NS. Venezuelan kindreds reveal that genetic and environmental factors modulate Huntington's disease age of onset. Proc Natl Acad Sci U S A. 2004;101:3498-503.

15. Correia K, Harold D, Kim KH, Holmans P, Jones L, Orth M, Myers RH, Kwak S, Wheeler VC, MacDonald ME, Gusella JF, Lee JM. The Genetic Modifiers of Motor Onset Age (GeM MOA) website: genome-wide association analysis for genetic modifiers of Huntington's disease. J Huntingtons Dis. 2015;4(3):279-84.

16. Simonin C, Duru C, Salleron J, Hincker P, Charles P, Delval A, Youssov K, Burnouf S, Azulay JP, Verny C, Scherer C, Tranchant C, Goizet C, Debruxelles S, Defebvre L, Sablonnière B, Romon-Rousseaux M, Buée L, Destée A, Godefroy O, Dür A, Landwehrmeyer B, REGISTRY Study of the European Huntington's Disease Network, Bachoud-Levi AC, Richard F, Blum D, Krystkowiak P. Huntington French Speaking Network. Association between caffeine intake and age at onset in Huntington's disease. Neurobiol Dis. 2013 Oct:58:179-82.

17. Swami M, Hendricks AE, Gillis T, Massood T, Mysore J, Myers RH, Wheeler VC. Somatic expansion of the Huntington's disease CAG repeat in the brain is associated with an earlier age of disease onset. Hum Mol Genet. 2009 Aug 15;18(16):3039-47.

18. Squitieri F, Esmaeilzadeh M, Ciarmiello A, Jankovic J. Caudate glucose hypometabolism in a subject carrying an unstable allele of intermediate CAG repeat length in the Huntington's disease gene. Mov Disord 2011;26: 925-7.

19. Green JB, Dickinson ES, Gunderman JR. Epilepsy in Huntington's chorea: clinical and neurophysiological studies. Adv Neurol. 1973;1:105-13.

20. Reinhold E. Schlagenhauff, P.K. Sethi. Electro-Clinical Findings in Huntington's Chorea. Clin Electroenceph. 1977;8:100-8. 
21. Lenti C, Bianchini E. Neuropsychological and neuroradiological study of a case of early-onset Huntington's chorea. Dev Med Child Neurol. 1993 Nov; 35(11):1007-10.

22. Levy G, Nobre ME, Cimini VT, Raskin S, Engelhardt E. Juvenile Huntington's disease confirmed by genetic examination in twins. Arq Neuropsiquiatr. 1999 Sep;57(3B):867-9.

23. Gambardella A, Muglia M, Labate A, Magariello A, Gabriele AL, Mazzei R, Pirritano D, Conforti FL, Patitucci A, Valentino P, Zappia M, Quattrone A. Juvenile Huntington's disease presenting as progressive myoclonic epilepsy. Neurology. 2001 Aug;57:708-11.

24. Vargas AP, Carod-Artal FJ, Bomfim D, Vázquez-Cabrera C, Dantas-Barbosa C. Unusual early-onset Huntingtons disease. J Child Neurol. 2003 Jun;18(6):429-32.

25. Milunsky JM, Maher TA, Loose BA, Darras BT, Ito M. XL PCR for the detection of large trinucleotide expansions in juvenile Huntington's disease. Clin Genet 2003:64:70-73

26. Duesterhus P, Schimmelmann BG, Wittkugel O, Schulte-Markwort M. Huntington disease: a case study of early onset presenting as depression. Am Acad Child Adolesc Psychiatry. 2004 Oct;43(10):1293-7.

27. Seneca S, Fagnart D, Keymolen K, Lissens W, Hasaerts D, Debulpaep S, Desprechins B, Liebaers I, De Meirleir L. Early onset Huntington disease: A neuronal degeneration syndrome. Eur J Pediatr. 2004;163:717-21.

28. Schapiro M, Cecil KM, Doescher J, Kiefer AM, Jones BV. MR imaging and spectroscopy in juvenile Huntington disease. Pediatr Radiol. 2004 Aug;34(8): 640-3.

29. Papapetropoulos S, Lopez-Alberola R, Baumbach L, Russell A, Gonzalez MA, Bowen BC, Singer C. Case of maternally transmitted juvenile Huntington's disease with a very large trinucleotide repeat. Mov Disord. 2005 Oct;20: 1380-3.

30. Nahhas FA, Garbern J, Krajewski KM, Roa BB, Feldman GL. Juvenile onset Huntington disease resulting from a very large maternal expansion. Am J Med Genet Part A. 2005;137A:328-31.

31. Heloísa H, Ruocco IL-C, Tiago L, Li LM, Cendes F. Clinical Presentation of juvenile Huntington disease. Arq Neuropsiquiatr. 2006;64(1):5-9.

32. Marconi S, Rizzo G, Capellari S, Scaglione C, Cortelli P, Martinelli P, Bonazza S. Eating disorder as a psychiatric onset of juvenile Huntington's disease. Am J Psychiatry. 2011 Oct; 168(10):1120-1.

33. Geevasinga N, Richards FH, Jones KJ, Ryan MM. Juvenile Huntington disease. J Paediatr Child Health. 2006 Sep;42(9):552-4.

34. Waugh JL, Miller VS, Chudnow RS, Dowling MM. Juvenile Huntington disease exacerbated by methylphenidate: case report. J Child Neurol. 2008 Jul;23(7):807-9.

35. Sakazume S, Yoshinari S, Oguma E, Utsuno E, Ishii T, Narumi Y, Shiihara T, Ohashi $\mathrm{H}$. A patient with early onset Huntington disease and severe cerebellar atrophy. Am J Med Genet A. 2009 Feb 15;149A(4):598-601.

36. Reyes Molón L, Yánez Sáez RM, López-Ibor Alcocer MI. Juvenile Huntington's disease: a case report and literature review. Actas Esp Psiquiatr. 2010 Sep-Oct; 38(5):285-94.

37. Sunwoo JS, Lee ST, Kim M. A case of juvenile huntington disease in a 6year-old boy. J Mov Disord. 2010 Oct;3(2):45-7.

38. Nicolas G, Devys D, Goldenberg A, Maltête D, Hervé C, Hannequin D, GuyantMaréchal L. Juvenile Huntington disease in an 18-month-old boy revealed by global developmental delay and reduced cerebellar volume. Am J Med Genet A. 2011 Apr;155A(4):815-8.

39. Wojaczyńska-Stanek K, Adamek D, Marszał E, Hoffman-Zacharska D. Huntington disease in a 9-year-old boy: clinical course and neuropathologic examination. J Child Neurol. 2006 Dec;21 (12):1068-73.

40. Chuo YP, Hou PH, Chan CH, Lin CC, Liao YC. Juvenile Huntington's disease presenting as difficult-to-treat seizure and the first episode of psychosis. Gen Hosp Psychiatry. 2012 Jul-Aug:34(4):436.e9-11.

41. Post B, van Belzen M, Marcelis C, Meijer FJ, Willemsen MA, van de Warrenburg BP. Early onset dystonia and parkinsonism with abnormal globus pallidal signal in MRI: a diagnostic challenge. Mov Disord. 2013 Dec;28(14):2035-6.

42. Monrad P, Renaud DL. Typical clinical findings should prompt investigation for juvenile Huntington disease. Pediatr Neurol. 2013 Apr;48(4):333-4.

43. Patra KC, Shirolkar MS. Childhood-onset (Juvenile) Huntington's disease: A rare case report. J Pediatr Neurosci. 2015 Jul-Sep;10(3):276-9.

\section{Submit your next manuscript to BioMed Central and we will help you at every step:}

- We accept pre-submission inquiries

- Our selector tool helps you to find the most relevant journal

- We provide round the clock customer support

- Convenient online submission

- Thorough peer review

- Inclusion in PubMed and all major indexing services

- Maximum visibility for your research

Submit your manuscript at www.biomedcentral.com/submit
Biomed Central 